\title{
Analyzing values-based modes of production and consumption: Community-supported agriculture in the Austrian Third Food Regime
}

\author{
Christina Plank $\cdot$ Robert Hafner $\cdot$ Rike Stotten
}

(C) The Author(s) 2020

\begin{abstract}
Current globalized agricultural and food systems operate with an unsustainable capitalist model of production and consumption. The middle and upper classes of the global North and, increasingly, of emerging economies live at the expense of the global South. This has been referred to as the "imperial mode of living". An alternative model of production and consumption that fosters localized food systems in the corporate food regime is community supported agriculture (CSA), which aims to redefine consumer-producer relations along not just economic values. Against this background, the paper introduces an interdisciplinary conceptual framework for values-based modes of production and consumption where three categories-institutions, values and materiality-inform the empirical analysis. It examines the extent to which CSA can realize their values-based approach and how they transform the third food regime. The paper links CSA to the currently dominant third food regime and shows that, so far, CSA is just a niche in Austria. In the Austrian context, different forms of solidarity and attachment to the community are central shared ideals of CSA members and their supporters. Those values also respect nature and its materiality. However, at the same time, CSA initiatives, when

C. Plank $(\bowtie)$

Department of Political Science, University of Vienna, Universitätsstraße 7, 1010 Vienna, Austria

E-Mail: christina.plank@univie.ac.at

Institute of Social Ecology, University of Natural Resources and Life Sciences,

Schottenfeldgasse 29, 1070 Vienna, Austria

R. Hafner

Institute of Geography and Regional Science, University of Graz, Heinrichstraße 36, 8010 Graz, Austria

E-Mail: research@ roberthafner.at

R. Stotten

Institute of Sociology, Mountain Research Unit, University of Innsbruck,

Universitätsstraße 15, 6020 Innsbruck, Austria

E-Mail: rike.stotten@uibk.ac.at
\end{abstract}


implemented in daily practices, are confronted with institutional, social and material challenges. These need to be addressed if CSA is to continue long-term.

Keywords Values-based modes of production and consumption · Food regime · Community supported agriculture $\cdot$ Austria

\section{Die Analyse von wertebasierten Produktions- und Konsumweisen: Solidarische Landwirtschaft in Österreichs Drittem Food Regime}

Zusammenfassung Gegenwärtige globalisierte Landwirtschafts- und Nahrungsmittelsysteme sind durch ein nicht nachhaltiges kapitalistisches Produktions- und Konsummodell charakterisiert. Die Mittel- und Oberklasse des Globalen Nordens, und in zunehmendem Maße auch von Schwellenländern, leben auf Kosten des Globalen Südens. Dies wird auch als ,imperiale Lebensweise“ bezeichnet. Ein alternatives Produktions- und Konsummodell, das lokalisierte Nahrungsmittelsysteme im Corporate Food Regime stärkt, ist die Solidarische Landwirtschaft (CSA, für community supported agriculture). Sie zielt darauf ab, KonsumentInnen-ProduzentInnen-Beziehungen anhand von mehr als wirtschaftlichen Faktoren neu zu definieren. Vor diesem Hintergrund führt unser Artikel ein interdisziplinäres analytisches Framework für wertebasierte Produktions- und Konsumweisen ein. Die empirische Analyse wird durch drei Kategorien - Institutionen, Werte und Materialität - geleitet, um zu untersuchen, in welchem Ausmaß CSAs ihren wertebasierten Ansatz umsetzen können und wie sie das Dritte Food Regime verändern. Der Artikel verbindet CSA mit dem derzeit dominierenden Dritten Food Regime und stellt dar, dass CSA in Österreich bisher nur in der Nische existiert. Werte wie Solidarität und die Verbindung zu Gemeinschaft sind wichtige zentrale Ideale für CSA-Mitglieder und ihre UnterstützerInnen. Diese Werte respektieren auch die Natur und ihre Materialität. Jedoch werden sie zur gleichen Zeit durch institutionelle, soziale und materielle Praktiken der CSA herausgefordert. Diese Herausforderungen müssen adressiert werden, wenn CSAs langfristig existieren sollen.

Schlüsselwörter Wertebasierte Produktions- und Konsumweisen · Food Regime · Solidarische Landwirtschaft · Österreich

\section{Introduction}

Our current dominant mode of capitalist production and consumption is based on the deeply anthropocentric view (Vincent 1998) that nature and humans exist to be exploited (Hafner 2018, p. 53). While this exploitation contributes to climate change and the global rise of social inequality (Sutherlin 2017; Ermann et al. 2018), the capitalist mode of production and consumption is upheld in two ways: On the one hand, it is controlled by transnational corporations, through unfair trade regimes (Bartley 2018; Grumiller et al. 2016) and economic structures that become increasingly financialized (Simon and Tittor 2014; Plank and Plank 2014). For the agricultural 
and food system, this has been termed the corporate food regime (Friedmann and McMichael 1989). On the other hand, the everyday practices embedded in these structures play an important role in reproducing this unsustainable mode of production and consumption. Our lifestyle is based on the externalization of costs, which Brand and Wissen $(2013,2018)$ refer to as "imperial mode of living", which reinforces unequal economic dependencies. In this way, traditional modes of production and consumption in the producer countries are violated and global and regional social inequality increases (Hafner et al. 2016; Plank 2016).

Against this background, we explore alternatives in the form of community supported agriculture (CSA) as values-based mode of production and consumption (VBMPC) with a focus on local production and consumption and on sharing values beyond the economic sphere (McMichael 2014; Hvitsand 2016). VBMPC is an important example within the food sovereignty movement that advocates democratic control of the agricultural and food system (Desmarais et al. 2017).

CSA is commonly discussed in the alternative food network (AFN) literature, which examines, for instance, the motivation of the producers (Galt et al. 2011) and the consumers (Bougheraraa et al. 2009; Brehm and Eisenhauer 2008; Cox et al. 2008), their practices (Hayden and Buck 2012) and up-scaling processes (Balázs et al. 2016; Nost 2014). AFN food supply chains usually involve the consumer (Whatmore and Clark 2006). They also rely on such aspects as organic, local or regional and specialty foods, fair trade relations and sales channels like farmers' markets, box schemes and CSA (Maye and Kirwan 2010). Within AFN literature, the concept of values-based supply chains (VBSC) (Stevenson and Pirog 2008; Marsden et al. 2000) serves as an alternative for mid-scale farms, which operate between short (direct) and long (conventional) supply chains. Those farms contribute to the rural livelihood and to sustainable regional development (Stotten et al. 2017; Renting et al. 2003). However, AFN literature has so far hardly addressed the wider politicalinstitutional and socio-economic background these supply chains are embedded in.

In this article, we draw on CSA as one popular initiative within the food sovereignty movement. We show that CSA can be understood as a testing ground for values-based modes of production and consumption (VBMPC), which attempt to leave the status quo behind and reshape dominant capitalist producer-consumer relations. We introduce an interdisciplinary conceptual framework to analyze values-based modes of production and consumption, based on three main categories: institutions, values and materiality. It enables us to examine how CSA can realize their values-based approach within the third food regime and how they aim to transform the latter through their values. Our findings show that CSA members and supporters in Austria largely share an understanding of the ideals CSA offers as an alternative to dominant modes of production and consumption. However, CSA in Austria are confronted with social, material and institutional challenges, which are partially addressed, but need greater attention if CSA is to prevail in the longer term.

After describing the interdisciplinary theoretical framework, we examine CSA in Austria. We focus on the institutional setting, values and materiality as well as on the tensions that arise between these dimensions and everyday practices. 


\section{Analyzing values-based modes of production and consumption within the corporate food regime}

We examine the interplay of CSA with the wider political-institutional and socioeconomic system it is embedded in. We understand CSA in the Austrian context as communities of producers and consumers, commonly referred to as 'eaters' ('ErnteteilerInnen' in German), sharing the risks of production. The latter fund the production for a season in advance and receive the produce on a weekly basis in return. Below we present an interdisciplinary conceptual framework that is embedded in the food regime literature and that draws on the concept of the imperial mode of living. This interdisciplinary approach is needed to address the challenges and opportunities of niche initiatives such as CSA in Austria.

In the food regime literature, "food from nowhere" (McMichael 2009) emphasizes the anonymity between producers and consumers over spatial distance. This distance was created by the first, UK-centred (1870-1930) food regime and further developed under the second, US-centered one (1940-1970). It provides a framework to study the global, political-economic and geopolitical development of agriculture and food. Important characteristics of the current third or corporate food regime (Friedmann and McMichael 1989; McMichael 2013) are the dominance of transnational corporations and the World Trade Organization (WTO), who support the regime through free-trade agreements, thus reinforcing social inequality. Overall, these globalized market structures make the survival of small-scale and peasant farmers extremely difficult.

Yet, embedded in the corporate food regime, CSA initiatives pursue a "food from somewhere" (McMichael 2009) approach or, in the case of Austria, "food from here" (Schermer 2015). As part of the food sovereignty movement and solidaritybased economy, they question the dominant mode of production and consumption and provide an alternative. It fosters the local scale (Akram-Lodhi 2015, p. 572f.; Schermer 2015) and includes ecological aspects and values such as fairness, trust and solidarity (McMichael 2014; Patel 2009).

Another reference point for our framework is the "imperial mode of living" (Brand and Wissen 2018), which focuses not only on dominant norms of consumption, but also on norms of production, distribution and on contextual elements of how society is organized. It links everyday life to societal structures and strengthens existing power relations through practices. Based on Gramsci's thought (1991, p. 1375), what supports the imperial mode of living is not only the underlying material component but also the ongoing discourses that create hegemony. Here, the term "imperial" emphasizes its global and ecological dimensions. Although the idea of hegemony is not based on coercion but on consensus, the mode of living is always contested. Thus, within the hegemonic imperial mode of living, there are always alternative modes of living.

Brand and Wissen (2018) point out four dimensions to analyze the imperial mode of living: (1) valorization, accumulation and reproduction, (2) hegemony and subjectification, (3) hierarchization and (4) externalization. These shall guide the analysis of the imperial mode of living within their framework. Brand and Wissen argue, that, to overcome the imperial mode of living, a social-ecological transformation, 
Fig. 1 Interdisciplinary conceputal framework for analyzing values-based modes of production and consumption

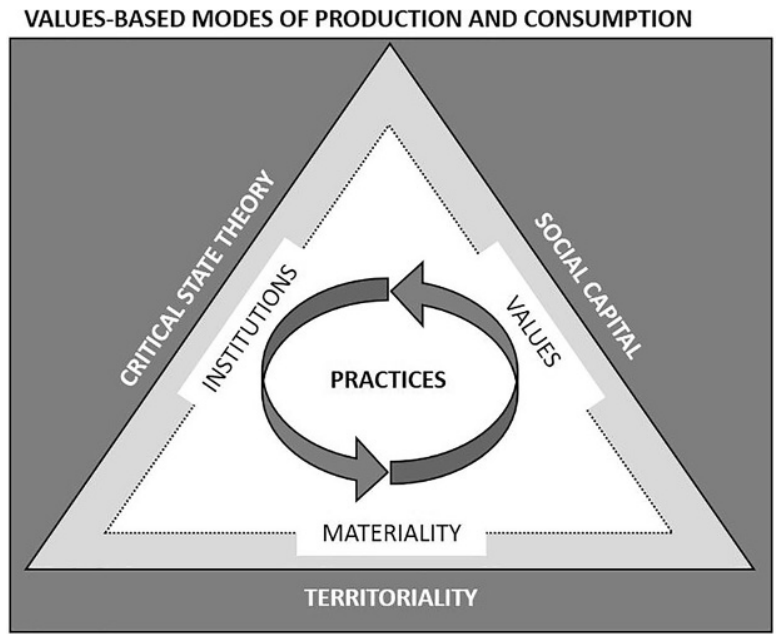

understood as different forms of societal reproduction that do not follow the logic of capital accumulation and domination, is necessary. Thus, niche projects, search processes, as well as strategic actions that challenge existing power relations and trigger conflicts and structural discontinuity, are needed.

Although inspired by the concept of the "imperial mode of living", we think that it is crucial to redefine the dimensions when analyzing alternatives in the capitalist system. In what follows, we show how initiatives that oppose "food from nowhere" can be investigated as VBMPC. We suggest an interdisciplinary conceptual framework that allows the examination of VBMPC based on critical state theory and theoretical approaches of social capital and territoriality that cover three analytical dimensions: (1) institutions, (2) values, and (3) materiality.

Fig. 1 shows institutions, values and materiality as the three defining categories of values-based modes of production and consumption. Depending on the different contexts, they influence and are being influenced by the respective practices of the involved actors. How they can be analyzed will be explained below.

\subsection{Institutions}

The state as an institution shapes the conditions for VBMPC. According to Poulantzas (2000 [1978]), the state can be understood as a social relation, emphasizing the role of the state as a contested terrain, and highlighting power relations that shape the state. It is interwoven with the economy, where the law is not neutral but an expression of social power relations that are inscribed in the state (Buckel and Fischer-Lescano 2007). Drawing on the strategic relational approach, it can be shown which social forces have access to the development of the state and co-determine it and vice versa (Jessop 2010). In this way, the transformation of the state can be examined. Critical state theory is important for our framework since the political-institutional dimension is crucial when analyzing agrarian change. A combination of critical state theory with Gramsci's concept of hegemony further allows 
examining how civil society is incorporated in the state and how consensus and domination are pursued (Buckel and Fischer-Lescano 2007). Building on critical state theory, we can highlight the interdependence of CSA with the state and how they are embedded in the national food regime. This further allows analyzing what political-institutional support would be necessary to anchor these initiatives in the wider socio-economic development or to up-scale them.

\subsection{Values}

Social capital refers to social relations and the underlying values that guide their performance. Such values motivate and organize the VBMPC. Social capital builds on "the information, trust, and norms of reciprocity inhering in one's social networks" (Woolcock 1998, p. 153). The bonding social capital (Putnam 2000) of CSA relies on values such as solidarity or the connection to the community. When analyzing consumer-producer relations in a capitalist system, the differentiation between use and exchange value makes us aware of the usefulness of certain goods that is the basis for exchange. The exchange value, however, does not mirror the use of a certain good (Marx 1962), for instance, taking into account that bread is less expensive than jewelry. Solidarity economies, which CSA is part of, stress the necessity of eliminating the exchange value. Producer-consumer relations must not be based on the price of a commodity but on the needs of society (Miller 2010). In the same manner, the role of solidarity and community needs to be emphasized. Stjernø (2005) differentiates between inclusive and exclusive solidarity. Thus, it can be investigated to what extent CSA includes farmers and consumers beyond a homogeneous group and which actors go along with what kind of solidarity.

\subsection{Materiality}

Food production and consumption is intrinsically linked to the physical space and its materiality. Materiality is considered an element of territoriality, which is used as a process connecting the structural and relational to the physical space (Haesbaert 2013; Raffestin 2012; Sack 1986). In so doing, the materiality of the physical becomes the basis for all social processes and arrangements (Becker and Otto 2016; Swyngedouw 2006). Consequently, materiality shapes society-nature relations. A key point along with the exploitation of humans and nature is the inability to control nature. Rather, attempts at controlling nature create even more dependence on nature and trigger or aggravate social-ecological conflicts. To put it another way, the materiality of nature must be seriously considered when creating VBMPC. In the case of CSA, this would imply, for instance, to take into account the socialecological impact of cultivation methods or to analyze how unfavourable weather conditions are addressed in the producer-consumer relations. Materiality considers two main components: the importance of spatiality and of natural resources. For the purpose of this paper, we focus on the materiality of natural resources. 


\section{Methods}

We used an explorative approach to investigate CSA in Austria. Out of approximately 30 CSA initiatives in Austria, we selected five-all of them situated in Eastern Austria - for in-depth research, considering different stages of the life cycle. The sampling aims to include a variety of different aspects like size, organization or ownership structure. Three were up-and-running initiatives (Bio-Fuchs, SoLaWi Radix and Höchweber in Styria), one was about to start (Ouvertura in Lower Austria) and one CSA had already stopped functioning (SoLaWi Sepplashof in Burgenland).

Due to our interdisciplinary background from political science, sociology and geography, we framed the types of interview according to the type of data expected from the interviewees (Hafner 2018, p. 31): (a) background data to obtain contextual insights into CSA in Austria; (b) structural data for more focused factual information on the workings of CSA; (c) perspectivist data to visualize the different ways of thinking in situ, particularly in relation to values. For the semi-structured interviews (Meuser and Nagel 2005), people with specific knowledge in their particular fields of activity and representative for their peer group were selected. Within each CSA community, expert interviews served to reveal insights into the functioning of the respective CSA. In total, 11 expert interviews were conducted in winter and spring 2017, mainly in person at places chosen by the interviewees. The interview with the CSA that was about to be established was carried out as a group interview; two interviews were conducted via Skype. In addition to the CSA representatives, experts from the institutional environment, i.e. agricultural lobby organizations, activists and NGOs, were interviewed. The interviews were transcribed verbatim and analyzed along deductive categories. Feedback loops allowed integrating inductively developed dimensions, included in the deductive categories (Mayring 2000).

\section{CSA as VBMPC}

CSA has its origins in the 1960s in various countries. Its common objective is to unite producers and eaters (Int1). Today, CSA is found worldwide and the initiatives vary according to the local political-economic and cultural context (Urgenci n.d.).

Austria's first initiative, GeLa Ochsenherz, was started in Lower Austria in Gänserndorf near Vienna in 2011. 'GeLa' stands for 'Gemeinsam Landwirtschaften', translated as collective farming. After the establishment of GeLa Ochsenherz, about 30 CSA initiatives started and spread primarily in the east of the country. Recently, CSA initiatives have sprung up especially near Graz (Styria) (Ernährungssouveränität Wiki 2018). In addition to their own produce, some initiatives expand their range of goods through cooperation with other farms (Int8, Int10).

Similar to other countries, the concrete arrangement of CSA in Austria varies from initiative to initiative (Urgenci n.d.). Depending on the fact whether the CSA was launched by eaters or producers, the reshaping of producer-consumer relations differs greatly. CSA initiatives initiated by eaters have more common structures on the decision-making process (Int9). In contrast, CSA initiatives founded by producers maintain rather separate producer-consumer relations, where they merely 
get in contact via the pick-up point or joint field walks (Int2). Yet all investigated CSA initiatives share their non-subordination to the paradigm of economic growth (Int1). In other words, CSA farms are not under the same economic pressure as conventional farms because they are financed by their members who guarantee their survival, altering institutional frameworks towards the inclusion of alternative values (Int6). Ideally, within CSA initiatives, the production has a price and not the product (Int1, Int5). The process becomes key, also alleviating the risks that encompass the materiality of food growing.

We now focus on the analysis of the three dimensions: institutions, values and materiality, and concentrate on how CSA farms are ideally perceived, what challenges they encounter and how these challenges could possibly be overcome.

\subsection{Austria's current institutional setting}

While there exists a vibrant network of institutions supporting CSA, political-institutional structures linked to Austria's conservative People's Party and the main representative organization of Austria's farmers, the Chamber of Agriculture, dominate the socio-economic and political-institutional setting of the agricultural sector. Even though Austria's joining the EU and opening towards the world market pushed these social forces to engage in direct marketing and organic agriculture, these strategies barely cover the fundamental problems of today's food regime. Consequently, the marginalization of small-scale farmers continues (Möhrs et al. 2013; Schermer 2015).

Fig. 2 shows two trends in the Austrian agricultural business structure. The number of farms is declining constantly, while the average agricultural area is growing. Consequently, from 1990 to 2018, the number of farms smaller than 50 ha fell (most affected are small farms up to 5 ha, where only 30\% of those in 1990 still exist), while farms larger than 50 ha are booming (Statistik Austria 2018). The motto 'up or out' stands for a structural change that is accompanied by a generation change in the Austrian agricultural system. As one representative of the organic farming association points out, the farmers' representative organization-the chamber of agriculture-does not take this development seriously enough: "Structures in the countryside are maybe irreversibly destroyed, or it is very difficult to repair them. This is known, but not enough is done against this" (Int3). Rather, the dominant political and economic forces declare this process of change inevitable. Moreover, even today, agriculture remains a very closed sector and a closed society (Int7), "protecting itself fiercely against career changers" (Int3). This complicates the involvement of newcomers in the sector (Int7).

The Nyéléni food sovereignty movement addresses these disadvantageous conditions in the agricultural and food system (Nyéléni Austria 2017). Several national forums and the European Forum on Food Sovereignty have taken place since 2011, supported by institutions such as ÖBV-Via Campesina Austria, FIAN (Food First Information and Action Network) or AgrarAttac (the agricultural subgroup of Attac). Groundbreaking for the dissemination of CSA initiatives was the European project 'CSA for Europe' in 2013, carried out by AgrarAttac. Further support for CSA has been under discussion by creating a national CSA network (Int5) and a position 


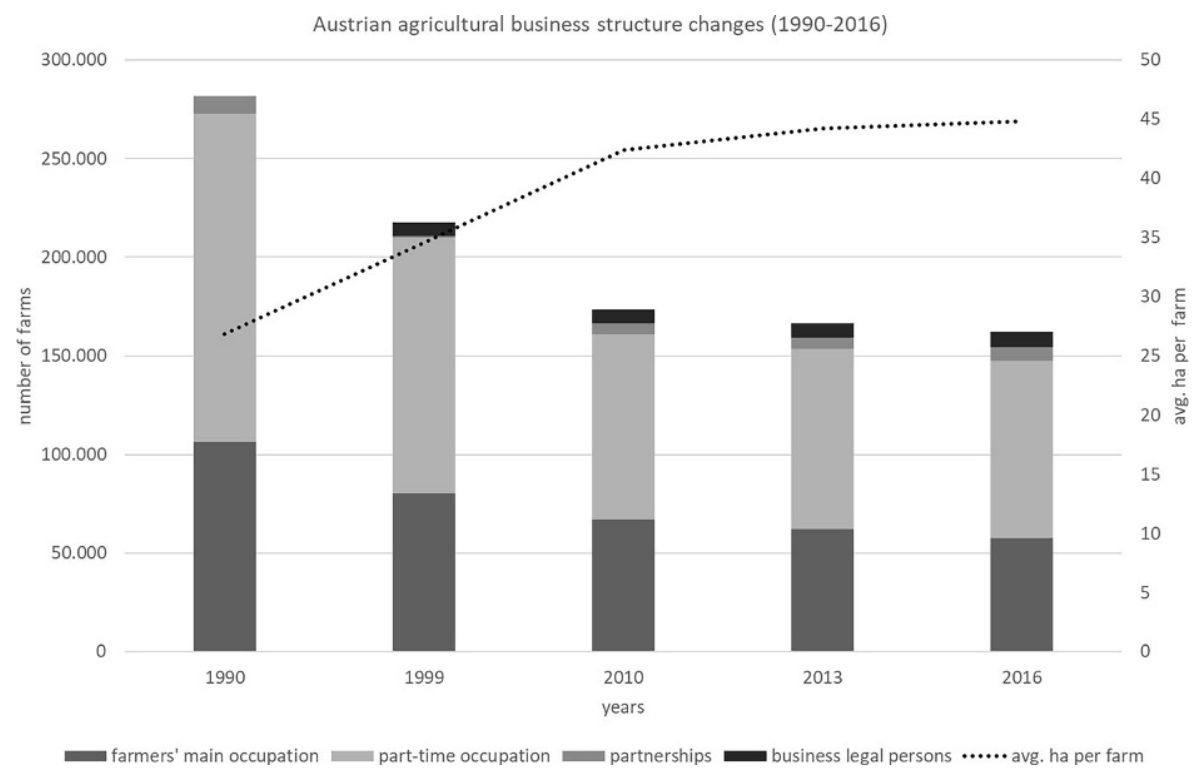

Fig. 2 Austrian agricultural business structure change (1990-2016). (Author's design, based on Statistik Austria 2018)

within the organization supporting organic agriculture in Styria, Austria's 'hot spot' for CSA (Int8).

Against this background, CSA represents an opportunity for people who want to foster a change of practice and become farmers engaging in small-scale and organic agriculture. The CSA model can serve as a kind of start-up initiative for this group (Int5, Int7). Altering institutional settings, CSA is "one of the few possibilities, where one can support smallholder farmers directly, without being suffocated by the pressure of the market, the industry or the agricultural lobby" (Int8). Furthermore, since autumn 2016, concrete plans exist between the CSA 'GeLa Ochsenherz' and the foundation 'Rasenna' to establish a common foundation that would guarantee land for organic agriculture via re-structuring property relations (Nyéléni Austria 2017). This re-structuring of property relations regarding land as well as initiatives supporting the extra-familiar succession of farms (Perspektive Landwirtschaft 2018) are underpinned by the wish to support small-scale, organic farming (Int3, Int5).

\subsection{Solidarity and connection to community as guiding values}

While CSA initiatives greatly differ in their underlying ideological system (permaculture, Catholicism, organic vegan cultivation, or political leftist thinking; Int2, Int6, Int9, Int10) - they share common values, which is best reflected in their understanding of solidarity and the connection to community.

The members of CSA farms emphasize the importance of a community of solidarity, understood as inclusive, universal solidarity in an emancipatory way. For example, a prospective CSA producer defined solidarity as a common mechanism 
where "not only I am well off, but all the others are well off, too" (Int6a). Another definition was "that one looks around what can be done in the local community and that one takes care of humans in the local community" (Int6b). An eater expressed the meaning of solidarity as "sharing, even though one has little" (Int4). Showing solidarity with the farm and creating a deep attachment to the farm was also often mentioned. Yet this solidarity is universal and goes beyond agriculture, as highlighted by another eater: "You are more and more aware of what the consequences of your actions are or what refraining from them would mean. (...) Where does solidarity end? Where does sustainability end? Where does respect end? (...) If one gets involved, then one cannot close one's eyes any longer and ignore things" (Int11).

Four spheres of solidarity can be differentiated within CSA: solidarity (i) between producers and eaters, (ii) amongst eaters, (iii) amongst producers, and (iv) within society, understood in a wider transnational and universal context.

The main solidary principle of CSA in Austria is risk sharing between producers and eaters. By eaters' pre-financing the farm and its activities on a monthly, quarterly or annual basis, the risks and benefits are divided among both groups. In addition, some CSA farms offer the option of co-working in the fields as a contribution to the initiative (Int6, Int10). Thus, eaters enable producers to farm and, at the same time, they engage in agriculture. "Consumers are released from their passive role and can take over greater responsibility for agriculture" (Int1). Risk sharing means that, for instance, in case of bad weather conditions, the harvest loss is covered by both groups. Also, political support structures that tend to favour large-scale agricultural enterprises can be circumvented to a certain extent via this form of direct support (Int5, Int7, Int10). There exists an "economic dependence in the best sense of the word, because as long as this is not hierarchical, it is good and reasonable" (Int5). Solidarity between producers and eaters thus enables the production of organic, locally produced high-quality food that equally benefits eaters and producers.

Solidarity amongst eaters is created, in particular, via the paid shares that are oriented towards an indicative value. Every eater contributes as much as he or she can afford, either financially or through participation on the field, to provide in total the sum and workload that is needed to run the farm (Int1). The eaters receive their share of produce either at a distribution point or they take it as ready-made portions in boxes. The first option again creates great opportunities for solidary sharing and exchange among eaters: taking as much as one needs for the week while leaving enough for the others (Int4). Solidarity amongst producers, in turn, is expressed via passing on information and experience, sharing best practices, or networking (Int8), "because there is no competition (...) and everybody is ready to introduce everybody to CSA who would like to get involved in it" (Int2).

Ultimately, solidarity can be understood within society, on a transnational level and in a universal sense. Even if there are only $3.9 \%$ of the workforce active in Austria's current agricultural sector (WKO 2018), food concerns everybody. However, "agriculture is very dependent on factors which it cannot influence (...) but society can-as the example of climate change shows" (Int5). In turn, rural infrastructure and rural life depends on the existence of smallholder farmers, who are supported via the CSA model (Int3). CSA and the realm of agriculture is one learning field where experiences can be made and transferred to other fields (Int4). By drawing 
on these experiences, living "a different form of social system" (Int4) should be enabled. Thus, practicing CSA is seen as a way of creating spillover effects for society (Int4).

Another key point is the connection to the community that creates close relationships and commitment. New qualitative in-depth links between producers and eaters arise by "growing together" (Int1) and enable the appreciation for the work of the producers. Receiving direct feedback from the eaters supports the farmer and is motivating for his work as expressed by one former CSA producer: "It's not like on the market, but we know the people, we see them every week and we get feedback like 'hey, the carrots were great' (...). This is much better for the self-affirmation and self-assessment of our work because one has direct contact to the people and gets recognition for one's work" (Int9). The community can empower people and make them confident to engage in agriculture (Int6a, d). Ideally, in the community everybody can do what s/he is good at (Int4), which is underpinned by negotiation processes, as an eater explains:

How do we handle this that we should agree together on what shall happen? How do we coordinate? How do we organize the common days at the farm? How do we get the food? How do we distribute it? Who takes care of this? Who is reliable, who is not? Or let's put it like this: we have areas that we are not good at. It's great then, when there is a constellation that is balanced, that some are better doing construction work and others are better at organizing. (Int4)

Eaters value food differently. They consume it in a more conscious way when they know where their food comes from, who produced it and how much work was put into the production (Int4). "You know this rhythm-gone after breakfast and back home at midnight. This is a challenge because it is a shame if the food goes bad. I would not say that this is even more of a problem with CSA food, but I feel closer to it. And I know how much work this meant for [the producer]" (Int4). Thanks to more conscious food consumption, CSA eaters could even save money compared to what they had spent before in the supermarket (Int10).

\subsection{Materiality}

The connection to nature and its materiality is explicit within CSA for producers and eaters alike. In CSA eaters get to know how vegetables can look in reality, unlike the homogeneous shapes of the vegetables sold in supermarkets (Int8). Producers let themselves "be surprised by nature" (Int8), asking "what is nature giving me today?" (Int8). This connection reinforces the ecological dimension of production as well as social-ecological interpretations of materiality. Producers do not have to throw away food, as they have to when selling produce on the market, because they know how much they need to harvest for their delivery. Furthermore, crop rotation is not only ecological and creates fewer problems with pests, it is also less capital intensive. It creates more security for the producer in case some seeds or plants do not grow (Int2). The use of pollinating varieties is widespread on CSA farms (Int2, Int8) and many aim to keep old varieties (Int4, Int8) and to use organic seeds (Int8). 
Taking care of the land and understanding nature is another common feature among CSA producers and eaters even though different ideological systems exist among them. Whereas producers who are involved in organic vegan agriculture refrain from using anything of farmed animal origin, considering them independent creatures with the right to a self-determined life (Int2), others aim for complementing vegetable production with sustainable egg production (Int6). All appreciate nature, which is an important driver for their commitment to CSA. "Being amazed or overjoyed about the very little things in the process of creation. (...) I am happy about every seedling (...) if this were not the case I could not run the farm (...), because there are enough adverse circumstances" (Int10).

\subsection{Tensions between practices, values, materiality and institutions}

The challenges for the daily practice of CSA in Austria and how they are met will be explained below in terms of institutional barriers, tensions between practices and values, and material constraints.

\subsubsection{Institutional constraints}

When CSA is put into practice, there are difficulties that are inscribed in the institutional system, i.e. the state, which poses barriers to the rise of CSA in Austria. Whereas some of these barriers specifically challenge CSA, others apply to smallscale agriculture and other types of collective farming as well.

First, the legal form holds difficulties for adequately capturing the structure of CSA initiatives. The majority of the CSA farms are still run as flat-rate individual enterprises (Int2, Int10), which simplifies taxation for the producer but does not incorporate more people in the management. Others have chosen the legal form of an association (Int6a) or a combination of both, which allows for integrating all CSA members. Since CSA challenges the capitalist system (oriented towards profit maximization), problems arise: "If you want to explain this [note: CSA] to a tax advisor, you need to take your time. He does not want to understand it because this is leading somewhere else. However, not everything needs to be directed towards profit, I do not know, maximizing profits. The system, however, does not understand this" (Int10).

Second, the question of the legal organization of work remains controversial. One major concern is that voluntary co-work on a CSA farm could be interpreted as illicit work. To counter this perception, it needs to be framed and highlighted as educational training. A further challenge for collectively managed farms is the social security and pension system, the costs for which form a large part of the expenses for CSA producers because, unlike for traditional family farms, there are no reductions available (Int2, Int7). The concerns about the legal insecurity for alternative initiatives within the third food regime were substantiated in a conflict concerning food co-ops in Upper Austria in 2016. The Austrian chamber of commerce accused food co-ops of not having a business license and of tax evasion (DerStandard 2016). The CSA network can help here by providing a platform for exchanging information, also on legal support (Int5). 
A third key challenge is state funding. Not only subsidies per hectare benefit mainly large-scale enterprises (Int4, Int10), grant applications are also rather orientated towards large-scale infrastructure with high investment sums (Int9). Smallscale investments for devices such as a milling machine are not supported. "One fits a bit into here and a bit into there, but truly one doesn't fit anywhere" (Int6b). To counter this pressure on land, the municipality could provide land (Int7). In particular, for vegetable production, less land and investment is needed than for arable or dairy farming (Int5).

Finally, dominant agricultural institutions frame CSA as another instrument of direct marketing (Jungbauern 2016), rather than as initiatives that fundamentally restructure our dominant mode of production and consumption. A major concern for the majority of CSA members interviewed is that a further dissemination of the CSA model might dilute it and its values-based approach (Int1). Most people engaged in CSA consider the CSA model as a true alternative to the capitalist system. CSA is appreciated as an experimental ground for new relations with society and nature, as a learning process of self-organization and negotiations, which can spill over to other societal fields (Int1, Int4).

\subsubsection{Value constraints}

Four points of tension between practices and values of CSA in Austria are identified.

First, CSA is a niche in Austria's agricultural system. The majority of CSA members have a higher than average level of education and income. Many initiatives are situated near cities in peri-urban areas and wealthier regions, where the predominantly middle-class CSA eaters live (Int9, Int11). This proximity to potential collaborators also means higher land prices for CSA farms. This begs the question whether the model could be spread to other regions and classes, as one producer said who had stopped CSA: "What we noticed is that in rural areas it is more difficult to ask for the same financial contributions as in Vienna or Graz. (...) So I wonder how the model can spread if it's only the middle class who can afford it" (Int9). One way to involve financially weak CSA members is to include them through a stronger engagement via co-working in CSA (Ouvertura n.d.).

A second challenge is the principle of risk sharing (c.f. Brown and Miller 2008; Galt et al. 2011; Hinrichs 2000; Ostrom 2007; Russell and Zepeda 2008; Lass et al. 2003). The CSA farmers interviewed did not pass on the full costs for the loss of the harvests. They either compensated the loss of vegetables with other kinds of produce available at that time (Int10), or reduced the share paid by the eaters (Int2). With the exception of one starting CSA initiative (Int6), producers were not willing to openly deal with the social pressure not to disappoint eaters. The starting initiative, however, communicated the intensified risk sharing component in the first year very openly by offering so-called "pioneer" shares (Int6). Another CSA farm changed strategy and currently - two years after the interview was carried out—stresses that, next to the share paid for the harvest, there is a share to be paid for investments to keep the farm running (Jaklhof n.d.). Providing a substantial basic income would counter this challenge (Int4). 
Third, even though economic pressure from the corporate food regime is reduced via consumers' pre-financing the production, social pressure is passed on to the producers who need to stand up for their needs and rights to leisure time or vacation (Int4). This kind of self-exploitation is also known from CSA farms in the USA (Ostrom 2007). As an agricultural lobby representative puts it: "From a social perspective, CSA is not thought through" (Int3). People that are well off pay producers in advance, but the risk sharing does not fully cover their share of other expenses like pension provision or social security. One activist has suggested reforming the social security system to counter institutional restrictions (Int7).

Fourth, time restrictions are present in everyday life in a negative way and effect the engagement of eaters in CSA initiatives. If there is no time for cooking, for processing the food, it goes bad (Int4, Int11). In a positive way, different levels of consciousness can change among CSA members over time. In particular, CSA farms initiated by producers need more time to engage the eaters as active CSA members (Int8, Int10). "The members do not take over responsibility immediately in the first two or three years" (Int1). For overcoming time constraints, the reduction of working hours from the 40-hour-week would help. This, however, is connected to the political-institutional setting (Int4). In addition, CSA producers know from experience that it is not the consumers that engage in direct marketing, e.g. customers of a farmer's market, who become active members of CSA. This means that even if an existing farm establishes CSA, new eaters are needed to run a CSA initiative (Int5, Int10).

\subsubsection{Material constraints}

Material constraints like severe weather conditions (Int1) or climate change (Int5) affect CSA farms like any other farm. Ideally, they can be better handled by the CSA risk sharing mechanism. However, there are limits to risk sharing connected to materiality, which were especially mentioned by the CSA farm that has withdrawn from production. Soil fertility influences the amount of work that needs to be dedicated to grow vegetables. Loamy soils and hillside locations do not provide ideal conditions for cultivating vegetables. Also, the availability of water is essential for cultivating vegetables. If the work invested cannot produce a sufficient amount of food to cover the shares (smaller amounts would make them too expensive), it can form a major barrier for continuing the farm (Int9).

One way to counter material challenges and to complement the intensive manual work is the use of specially designed tools, such as a ridge plough, which was created for one CSA farm (Int10). Other difficulties, such as vegetables going off during storage for the winter during the first year, were met by improving storage methods (Int2).

Producers and eaters interviewed both underlined that through CSA it becomes clear that we need to accept our dependence on nature and our limits of control over it. This becomes obvious, for instance, when CSA farms harvest wild plants (Int6d) or when plum trees have a bumper crop one year and none the following year (Int4). The eaters interviewed stressed that it is good that they cannot control everything. A certain material restriction has the advantage that they do not need to 
choose between a seemingly unlimited variety of products in the supermarket (Int4, Int11):

Because some things do not grow how you have planned them. Some grow much faster than you have planned. Then I go around and look what is ripe. Sometimes these are not the things that I thought of. Sometimes nature gives me completely different things. But there is always enough of it. And this is exciting. (Int8)

Starting CSA producers and organizers also highlighted that it is important to communicate what is possible and what is not feasible. For instance, even if eaters would prefer receiving less wheat products, the CSA farm might have to offer wheat in the beginning because this is the only plant suitable for their soil (Int6c). Creating awareness and understanding for different climatic zones and different production conditions and their effect on the agricultural and food system is therefore a crucial process (Int4).

\section{Conclusion}

Taking CSA as a concrete example of restructuring producer-consumer relations against the background of the corporate food regime and the imperial mode of living, we focused on the analysis of alternative developments in the agriculture and food system. We introduced an interdisciplinary conceptual framework that allowed analyzing CSA as VBMPC along three dimensions (institutions, values and materiality) to examine how CSA initiatives can realize their values-based approach within the Austrian third food regime and transform it based on their values. Although CSAs and their supporters have a similar understanding of the ideals of CSA, and their practices contribute to change, institutional, social and material challenges have to be taken seriously to guarantee the survival of CSA in Austria.

The difficult framework conditions for small-scale and organic farming are increasinlgy noticable in the Austrian third food regime and have led to a growing movement promoting alternatives in the agriculture and food sector. Since the establishment of the first CSA farm in Austria in 2011, the CSA initiatives have spread across the country. Today, CSA can be considered an important niche within Austria's third food regime that allows for experimenting VBMPC. CSA farms do not only produce agricultural goods but also play an important role for the local community and the ecological balance.

Considering CSA as an experimental field for VBMPC, we showed that the value of universal solidarity and the connection to the community of eaters and producers as well as the recognition of the materiality of nature are crucial for CSA initiatives in Austria. Yet, tensions arose in everyday practices about the full implementation of risk sharing, the engagement of eaters. Moreover, the producers experienced social pressure and biophysical constraints. Predominantly situated in peri-urban regions and connected to cities as centres of growth, which they rely on, CSA initiatives are further obstructed by institutional constraints on their legal form, the organization of work, and state funding. 
Whereas material constraints can be influenced to a lesser extent and are rather seen as something that needs to be accepted by CSA members, tensions between everyday practices and values and institutions can be addressed. There is a strong connection between values and sometimes seemingly unchangeable institutional barriers. In contrast to material limits, these institutions can be changed. This is a mutual process, where both the appreciation of food and the work of farmers need to be heightened in society, and the unequal production conditions for smallholder farmers in the globalized economic system need to be altered. For this struggle, the role of the food sovereignty movement is vital.

Providing local alternatives is important to act against the corporate food regime. Through localized production and consumption, production and consumption are taken out of the globalized market structures, thereby decreasing dependency on the corporate food regime. CSA exploits nature less than dominant forms of industrial agriculture. It also exploits humans less, even though self-exploitation of CSA producers is a pending risk of the model. By providing an opportunity for small-scale farmers, CSA shows alternatives to the corporate system, establishing collectively managed farms.

Confronting the imperial mode of living with VBMPC points out the limits of the analysis and gaps for future research. The inequality between producers and eaters needs to be further explored in connection with changes in the politicalinstitutional system necessary to support CSA. This could include the support of farm succession, how municipalities can assist CSA initiatives and an analysis of how CSA is embedded in infrastructure development, the economy cycle and issues of rural-urban development. Furthermore, since CSA is only in its infancy in Austria, an analysis is needed on how CSA is being transformed mid- to long-term and what impacts it has on the third food regime. Even if CSA is not meant to be another instrument of direct marketing, but to truly restructure producer-consumer relations, the open question remains whether CSA will gain support or be co-opted by the dominant agricultural system in the future, like what happened with other alternatives on producer-consumer relations in Austria's third food regime.

\subsection{List of interviews}

- Interview 1: CSA activist, Vienna, 27 January 2017

- Interview 2: CSA producer (farm owner), near Graz, 29 January 2017

- Interview 3: representative of an agricultural lobby organization, Graz, 7 February 2017

- Interview 4: CSA eater (organizer), Graz, 7 February 2017

- Interview 5: representative of an agricultural lobby organization, Vienna, 8 February 2017

- Interview 6: starting CSA producers (farm workers and organizers), group interview, Vienna, 17 February 2017

- Interview 7: activist, Vienna, 29 March 2017

- Interview 8: CSA producer (farm owner), Graz, 31 March 2017

- Interview 9: former CSA producer (farm owner), Graz, 31 March 2017 


\section{- Interview 10: CSA producer (farm owner), near Graz, 31 March 2017}

- Interview 11: CSA eater (consumer), Graz, 1 April 2017

\section{All interviews were conducted in German and are translated by the authors.}

Acknowledgements We thank the two anoymous reviewers and the editors of this Special Issue for their valuable feedback.

Funding This research was supported by the Vienna Science and Technology Fund (WWTF) through project ESR17-014. The empirical research was conducted under the Schasching post-Doc fellowship 2016/2017 at the ksoe, the Austrian Catholic Social Academy.

Funding Open access funding provided by University of Vienna.

Open Access This article is licensed under a Creative Commons Attribution 4.0 International License, which permits use, sharing, adaptation, distribution and reproduction in any medium or format, as long as you give appropriate credit to the original author(s) and the source, provide a link to the Creative Commons licence, and indicate if changes were made. The images or other third party material in this article are included in the article's Creative Commons licence, unless indicated otherwise in a credit line to the material. If material is not included in the article's Creative Commons licence and your intended use is not permitted by statutory regulation or exceeds the permitted use, you will need to obtain permission directly from the copyright holder. To view a copy of this licence, visit http://creativecommons.org/licenses/by/4. $0 \%$

\section{References}

Akram-Lodhi, Haroon A. 2015. Accelerating towards food sovereignty. Third World Quarterly 36(3):563583. https://doi.org/10.1080/01436597.2015.1002989.

Balázs, Bálint, György Pataki, and Orsolya Lazányi. 2016. Prospects for the future: community supported agriculture in Hungary. Futures 83:100-111. https://doi.org/10.1016/j.futures.2016.03.005.

Bartley, Tim. 2018. Transnational corporations and global governance. Annual Review of Sociology 44:145-165. https://doi.org/10.1146/annurev-soc-060116-053540.

Becker, Sören, and Antje Otto. 2016. Editorial: Natur, Gesellschaft, Materialität: aktuelle Herausforderungen der Politischen Ökologie. Geographica Helvetica 71(4):221-227. https://doi.org/10.5194/gh-71221-2016.

Bougheraraa, Douadia, Gilles Grolleaub, and Naoufel Mzoughic. 2009. Buy local, pollute less: what drives households to join a community supported farm? Ecological Economics 68:1488-1495.

Brand, Ulrich, and Markus Wissen. 2013. Crisis and continuity of capitalist society-nature relationships. The imperial mode of living and the limits to environmental governance. Review of International Political Economy 20(4):687-711. https://doi.org/10.1080/09692290.2012.691077.

Brand, Ulrich, and Markus Wissen. 2018. The limits to capitalist nature. Theorizing and overcoming the imperial mode of living. London, New York: Rowman \& Littlefield.

Brehm, Joan M., and Brian W. Eisenhauer. 2008. Motivations for participating in Community Supported Agriculture and their relationship with community attachment and social capital. Southern Rural Sociology 23(1):94-115.

Brown, C., and S. Miller. 2008. The impacts of local markets: a review of research on farmers markets and community supported agriculture (CSA). American Journal of Agricultural Economics 90(5):1298-1302.

Buckel, Sonja, and Andreas Fischer-Lescano. 2007. Hegemonie gepanzert mit Zwang. Zivilgesellschaft und Politik im Staatsverständnis Antonio Gramscis. Baden-Baden: Nomos.

Cox, Rosie, Lewis Holloway, Laura Venn, Liz Dowler, Jane Ricketts Hein, Moya Kneafsey, and Helen Tuomainen. 2008. Common ground? Motivations for community-supported agriculture scheme. Local Environment 13(3):203-218. https://doi.org/10.1080/13549830701669153.

DerStandard. 2016. "Food-Coops": Wirtschaftskammer will Kooperativen anzeigen. http://derstandard.at/ 2000035272847/FoodCoops-Wirtschaftskammer-will-Einkaufsgemeinschaften-anzeigen (Created 20 Apr 2016). Accessed 20 Feb 2017.

Desmarais, Anette A., Priscilla Claeys, and Amy Trauger (eds.). 2017. Public policies for food sovereignty: Social movements and the state. London: Routledge. 
Ermann, Ulrich, Ernst Langthaler, Marianne Penker, and Markus Schermer. 2018. Agro-food studies: Eine Einführung. Köln, Weimar, Wien: Böhlau.

Ernährungssouveränität Wiki. 2018. Solidarische Landwirtschaft. http://www.ernährungssouveränität.at/ wiki/Solidarische_Landwirtschaft. Accessed 15 Jan 2017.

Friedmann, Harriet, and Philip McMichael. 1989. Agriculture and the state system: the rise and decline of national agricultures, 1870 to the present. Sociologia Ruralis 29(2):93-117. https://doi.org/10.1111/ j.1467-9523.1989.tb00360.x.

Galt, Ryan, Libby O'Sullivan, Jessica Beckett, and Colleen C. Hiner. 2011. Community Supported Agriculture (CSA) in and around California's Central Valley: Farm and Farmer Characteristics, FarmMember Relationships. Economic Viability and Emerging Issues, August 2011. Davis: University of California.

Gramsci, Antonio. 1991. Gefängnishefte, 11th edn., Hamburg, Berlin: Argument.

Grumiller, Jan, Werner Raza, and Bernhard Tröster. 2016. The EU trade regime and the global south. Austrian Journal of Development Studies 32(3):4-15. https://doi.org/10.20446/JEP-2414-3197-323-4.

Haesbaert, Rogério. 2013. A global sense of place and multi-territoriality: notes for dialogue from a 'peripheral' point of view. In RGS-IBG book series. Spatial politics: essays for Doreen Massey, 1st edn., ed. David Featherstone, Joe Painter, 146-157. Malden: Wiley-Blackwell.

Hafner, Robert. 2018. Environmental justice and soy agribusiness. Abington, New York: Routledge.

Hafner, Robert, Gerhard Rainer, Fernando Ruiz Peyré, and Martin Coy. 2016. Ressourcenboom in Südamerika: Alte Praktiken - Neue Diskurse? Zeitschrift für Wirtschaftsgeographie 60(1-2):25-39. https://doi.org/10.1515/zfw-2016-0002.

Hayden, Jennifer, and Daniel Buck. 2012. Doing community supported agriculture: tactile space, affect and effects of membership. Geoforum 43:332-341. https://doi.org/10.1016/j.geoforum.2011.08.003.

Hinrichs, C.C. 2000. Embeddedness and local food systems: notes on two types of direct agricultural market. Journal of Rural Studies 16(3):295-303.

Hvitsand, Christine. 2016. Community supported agriculture (CSA) as a transformational act—distinct values and multiple motivations among farmers and consumers. Agroecology and Sustainable Food Systems 40(4):333-351. https://doi.org/10.1080/21683565.2015.1136720.

Jaklhof (n. d.) Jaklhof. Wir säen Zunkunft. http://www.jaklhof.at/. Accessed 14 May 2019.

Jessop, Bob. 2010. State power: a strategic-relational approach. Cambridge: Polity.

Jungbauern. 2016. Innovative Vermarktungsformen für die Landwirtschaft. http://jungbauern.at/wpcontent/uploads/2016/11/IVF_brosch\%C3\%BCre_web_small.pdf. Accessed 3 Feb 2017.

Lass, Daniel, Ashley Bevis, G.W. Stevenson, John Hendrickson, and Kathy Ruhf. 2003. Community Supported Agriculture entering the 21st century: results from the 2001 national survey. Amherst: University of Massachusetts, Department of Resource Economics. http://www.cias.wisc.edu/wp-content/ uploads/2008/07/csa_survey_01.pdf. Accessed 4 Mar 2019.

Marsden, Terry, Jo Banks, and Bristow Gillian. 2000. Food supply chain approaches: exploring their role in rural development. Sociologia Ruralis 40(4):424-438. https://doi.org/10.1111/1467-9523.00158.

Marx, Karl. 1962. Das Kapital. Kritik der politischen Ökonomie. Vol. 1. Berlin: Dietz.

Maye, Damian, and James Kirwan. 2010. Alternative food networks, sociology of agriculture and food entry for sociopedia.isa. http://www.sagepub.net/isa/resources/pdf/AlternativeFood-Networks.pdf. Accessed 3 Mar 2019.

Mayring, Philipp. 2000. Qualitative content analysis. Forum qualitative social research 1(2), Art. 20. http:// www.qualitative-research.net/index.php/fqs/article/view/1089/2386. Accessed 3 Feb 2017.

McMichael, Philip. 2009. A food regime genealogy. The Journal of Peasant Studies 36(1):139-169. https:// doi.org/10.1080/03066150902820354.

McMichael, Philip. 2013. Food regimes and agrarian questions. Halifax and Winnipeg: Fernwood Publishing.

McMichael, Philip. 2014. Historicizing food sovereignty. The Journal of Peasant Studies 41(6):933-957. https://doi.org/10.1080/03066150.2013.876999.

Meuser, Michael, and Ulrike Nagel. 2005. ExpertInneninterviews - vielfach erprobt, wenig bedacht. Ein Beitrag zur qualitativen Methodendiskussion. In Das Experteninterview. Theorie, Methode, Anwendung, ed. Alexander Bogner, Beate Littig, and Wolfgang Menz, 71-93. Wiesbaden: VS.

Miller, Ethan. 2010. Solidarity economy: key concepts and issues. In Solidarity economy: building alternatives for people and planet, ed. Emily Kawano, Tom Masterson, and Jonathan Teller-Ellsberg, 1-12. Amherst: Center for Popular Economics.

Möhrs, Kim, Franziskus Forster, Sarah Kumnig, and Lukas Rauth. 2013. The politics of land and food in cities in the North: Reclaiming urban agriculture and the struggle Solidarisch Landwirtschaften! 
(SoliLa!) in Austria. In Land concentration, land grabbing and people's struggles in Europe, ed. Jenny Franco, Saturnina M. Borras Jr., 96-127. https://www.tni.org/files/download/07._austria.pdf. Retrieved 3.2.2017.

Nost, Eric. 2014. Scaling-up local foods: commodity practice in community supported agriculture (CSA). Journal of Rural Studies 34:152-160. https://doi.org/10.1016/j.jrurstud.2014.01.001.

Nyéléni Austria. 2017. Munus Stiftung - Allmende für Gutes Leben. http://www.ernährungssouveränität.at/ munus-stiftung-allmende-fuer-gutes-leben/. Accessed 3 May 2019.

Ostrom, M. 2007. Community supported agriculture: is it working? In Remaking the north American food system, ed. C. Hinrichs, T. Lyson, 99-120. Lincoln: University of Nebraska Press.

Ouvertura. 2017. Ouvertura. Solidarische Landwirtschaft. https://www.ouvertura.at/. Accessed 3 Feb 2017.

Patel, Raj. 2009. Food sovereignty. The Journal of Peasant Studies 36(3):663-706.

Perspektive Landwirtschaft. 2018. https://www.perspektive-landwirtschaft.at/. Accessed 5 May 2019.

Plank, Christina. 2016. The agrofuels project in Ukraine: How the oligarchs and the EU foster agrarian injustice. In Fairness and Justice in Natural Resource Politics, ed. Melanie Pichler, Cornelia Staritz, Karin Küblböck, Christina Plank, Werner Raza, and Fernando Ruiz Peyré, 218-236. London: Routledge.

Plank, Christina, and Leonhard Plank. 2014. The financialisation of farmland in Ukraine. Austrian Journal of Development Studies 30(2):46-68.

Poulantzas, Nicos. 2000. State, power, socialism. London, New York: Verso.

Putnam, Robert. 2000. Bowling alone: the collapse and revival of American community. New York: Simon and Schuster.

Raffestin, Claude. 2012. Space, territory, and territoriality. Environment and Planning D: Society and Space 30(1):121-141. https://doi.org/10.1068/d21311.

Renting, Henk, Terry K. Marsden, and Jo Banks. 2003. Understanding alternative food networks: exploring the role of Short Food Supply Chains in rural development. Environment and Planning A 35:393-411.

Russell, S., and L. Zepeda. 2008. The adaptive consumer: shifting attitudes, behavior change and CSA membership renewal. Renewable Agriculture and Food Systems 23(2):136-148.

Sack, Robert D. 1986. Human territoriality: Its theory and history. Cambridge studies in historical geography, Vol. 7. New York: Cambridge University Press.

Schermer, Markus. 2015. From "Food from Nowhere" to "Food from Here": changing producer-consumer relations in Austria. Agriculture and Human Values 32:121-132. https://doi.org/10.1007/s10460014-9529-z.

Simon, Jenny, and Anne Tittor. 2014. The financialisation of food, land, and nature (introduction). Austrian Journal for Development Studies 30(2):4-15.

Statistik Austria. 2018. Agrarstrukturerhebung. http://www.statistik.at/web_de/statistiken/wirtschaft/land_ und_forstwirtschaft/agrarstruktur_flaechen_ertraege/betriebsstruktur/index.html. Accessed 18 Apr 2019.

Stevenson, G.W., and Richard Pirog. 2008. Values-based supply chains: strategies for agrifood enterprises of the middle. In Food and the mid-level farm: renewing an agriculture of the middle, ed. G.W. Stevenson, R. Welsh, and T.A. Lyson, 119-143. Cambridge, MA: MIT Press.

Stjernø, S. 2005. Solidarity in Europe. The history of an idea. Cambridge: University Press.

Stotten, Rike, Sybille Bui, Patrizia Pugliese, Markus Schermer, and Claire Lamine. 2017. Organic valuesbased supply chains as a tool for territorial development: a comparative analysis of three European organic regions. International Journal of Sociology of Agriculture and Food 24(1):135-154.

Sutherlin, John W. 2017. Ethics, environmental justice and climate change. Science and Public Policy 44:578-598. https://doi.org/10.1093/scipol/scw081.

Swyngedouw, Eric. 2006. Metabolic urbanization. The making of cyborg cities. In Questioning cities series. In the nature of cities: urban political ecology and the politics of urban metabolism, ed. Eric Swyngedouw, Maria Kaik, and Nik Heynen, 20-39. London, New York: Routledge.

Urgenci-The International Network for Community Supported agriculture. 2019. https://urgenci.net/. Accessed 5 May 2019.

Vincent, Andrew. 1998. Is environmental justice a misnomer? In Social justice. From hume to Walzer, ed. David Boucher, P.J. Kelly, 123-145. London: Taylor \& Francis Ltd.

Whatmore, S., and N. Clark. 2006. Good food: ethical con-sumption and global change. In $A$ world in the making, ed. N. Clark, D. Massey, and P. Sarre, 363-412. Milton Keynes: The Open University.

WKO. 2018. WKO Statistik Basisdaten für Österreichs Bundesländer, 26.04.2019. http://wko.at/statistik/ bundesland/w.pdf. Accessed 5 May 2019.

Woolcock, Michael. 1998. Social capital and economic development: toward a theoretical synthesis and policy framework. Theory and Society 27(2):151-208. https://doi.org/10.1023/A:1006884930135. 
Christina Plank is a visiting professor at the Department of Political Sciences at the University of Vienna. Her research focuses on critical state theory, political ecology and social-ecological transformation in the context of agriculture and food, with a regional focus on Central and Eastern Europe. Recent publications deal with agrofuels, particularly the agrofuels project in Ukraine, land grabbing or food sovereignty.

Robert Hafner is a guest professor at the Institute of Geography and Regional Science at the University of Graz. The themes of his research concern the relationship of humans with the environment, with a special focus on environmental justice and soy/food production in the global South and comparative studies on waste management at the interlinkage between the global South and global North. Methodologically, he focuses on the (re)development of human-environment, affective and visceral approaches towards multisensory forms of cognition.

Rike Stotten holds a $\mathrm{PhD}$ in Sociology and is a research associate and lecturer at the Department of Sociology, Mountain Research Unit, at the University of Innsbruck. Her research interests are in the area of visual qualitative research, agri-food studies and rural sociology in mountain areas. Currently she is PI of an interdisciplinary project funded by the Austrian Academy of Sciences on farm and community resilience in mountain areas. 